\title{
Pääkirjoitus
}

\section{Puheviestinnän vuosikirja Prologi uudistusten tiellä}

Elämme sukupolvemme merkittävintä juhlavuotta, sillä vuonna 2017 Suomi täyttää 100 vuotta. Vuosi on tuonut mukanaan useita erilaisia projekteja, juhlia, esityksiä, selontekoja ja visioita tulevasta. Yksi niistä on Opetus- ja kulttuuriministeriön lokakuussa 2017 julkaisema korkeakoulutuksen ja tutkimuksen visio 2030. Se on koostettu laajassa yhteistyössä korkeakouluyhteisön ja sidosryhmien kanssa ja sen tueksi laaditaan muun muassa kehittämisohjelmia. Visiossa mainitaan, että vuonna 2030 Suomessa arvostetaan sivistystä, tiedettä ja osaamista. Tulevaisuudessa tarvitsemmekin uudenlaista osaamista sekä enemmän korkeakoulutettuja osaajia. Lisäksi tarvitsemme muuan muassa yhdessä tekemisen kulttuuria ja siitä kumpuavaa osaamisen edelläkävijyyttä. (Korkeakoulutuksen ja tutkimuksen visio 2030.) Yhteistoiminta edellyttää vuorovaikutusta ja jaettujen merkitysten rakentamista toimijoiden kesken. Yhteistyön tulokset rakennetaan siis vuorovaikutuksessa, jolloin myös osallistujien vuorovaikutusosaamisella on tärkeä rooli sekä tehtäväkeskeisyyden että suhdekeskeisyyden näkökulmista. Tehokas, tarkoituksenmukainen ja eettinen yhteistyö ei aina ole ongelmatonta ja oman vivahteensa siihen tuovat myös kansainväliset digitaaliset työympäristöt. Tulevaisuudessa tarvitaankin edelleen uutta tietoa ja ymmärrystä ihmisten välisestä vuorovaikutuksesta sekä siihen vaikuttavista tekijöistä eri konteksteissa.
Vuorovaikutuksen perustutkimuksella ja soveltavalla tutkimuksella on varmasti vahva paikkansa tulevaisuuden Suomessa. Vuorovaikutus on tutkimuskohteena kiehtova, moniulotteinen ja tärkeä. Siihen on mahdollista tarttua monitieteisesti ja tuottaa näin kiinnostavaa uutta tietoa. Meille vuorovaikutuksen tutkijoille onkin keskeistä, että meillä on myös oma tieteellinen julkaisu - Puheviestinnän vuosikirja Prologi - joka keskittyy julkaisemaan nimenomaan ihmisten väliseen vuorovaikutukseen liittyvää tuoretta tutkimusta. Prologi tarjoaa mahdollisuuden julkaista monitieteellistä tutkimusta ja täten se pyrkii juuri lisäämään yhteistyötä eri alojen asiantuntijoiden kanssa. Vaan millainen on visio tulevaisuuden Prologista tieteellisenä julkaisukanavana? Millaisia mahdollisia uudistuksia Prologi tarvitsee? Tämän vuoden toimituskunnassa on käyty keskustelua siitä, kuinka Prologin julkaisupolitiikkaa voisi uudistaa. Päädyimme kolmeen keskeiseen uudistukseen, jotka esittelen seuraavaksi.

Historiansa aikana Prologi on keskittynyt julkaisemaan suomenkielistä tutkimusta, joskin mukana on vuosien varrella ollut myös muilla kielillä kirjoitettuja tekstejä (esimerkiksi keynote-esitelmiin perustuneita puheenvuoroja). Ensinnäkin pohdimme toimituskunnassa, voisiko Prologissa julkaista vuorovaikutuksen uusinta tutkimusta myös ruotsin ja englannin kielillä, jotta tavoittaisimme suuremman yleisön vuorovaikutuksen tutkijoiden joukossa. Moni 
suomalainenkin tutkija voi haluta julkaista tutkimuksensa englanniksi tavoittaakseen laajemman lukijakunnan. Lisäksi yhä useammat suomalaisissa yliopistoissa tehtävät väitöskirjat ovat englanninkielisiä. Suomessa järjestetään useita kansainvälisiä konferensseja, joiden osallistujat voisivat haluta kirjoittaa vuorovaikutukseen liittyvästä aiheestaan Prologiin, mutta eivät tällä hetkellä pysty sitä kielen vuoksi tekemään. Kielikysymyksestä on keskusteltu aiemminkin Prologos ry:n jäsenten keskuudessa sekä Prologin toimituskunnassa. Muun muassa entinen Prologin päätoimittaja Marko Siitonen kirjoittaa asiasta pääkirjoituksessaan vuonna 2015. Kielikysymystä käsiteltiin uudelleen Prologos ry:n johtokunnan kokouksessa marraskuussa 2017 ja päätettiin, että vuoden 2018 aikana toimituskunta valmistelee yhdistyksen jäsenten kanssa yhteistyössä kirjoitusohjeet myös ruotsin ja englannin kielillä. Vuoden 2018 Prologiin voi tarjota artikkeliehdotuksia suomeksi, ruotsiksi ja englanniksi. Toimitustyö ja vuorovaikutus toimituskunnan kanssa tapahtuu vuonna 2018 suomeksi. Kotimainen ja kotimaisilla kielillä tapahtuva vuorovaikutuksen tutkimuksen julkaiseminen on edelleen Prologin keskiössä, mutta laajentamalla kielivalikoimaa haluamme myös avata mahdollisuuden uudenlaiseen yhteistyöhön vuorovaikutuksen tutkijoiden kesken.

Toinen keskeinen uudistusehdotuksemme liittyy Prologin toimituskunnan jäsenten mahdollisuuteen tarjota artikkeleita julkaistavaksi lehdessä. Tätä ennen toimituskunnan jäsenten ei ole ollut mahdollista tarjota tutkimuksiaan julkaistavaksi Prologissa niin kauan kuin he ovat toimituskunnan työssä mukana. Syksyllä 2017 ehdotimme sääntömuutosta Prologos ry:n johtokunnalle ja johtokunta päätti marraskuun kokouksessaan, että toimituskunnan jäsenten on mahdollista tarjota Prologiin tutkimusartikkeleita, joissa he ovat mukana kirjoittajina tai kanssakirjoittajina. Tällöin toimituskunnan jäsen ei saa kuitenkaan osallistua ko. tekstiä koskevaan arviointiprosessiin millään tavalla. Tämän päätettiin olevan mahdollista jo vuonna 2018. Toimitustyössä noudatetaan tarkasti Tieteellisten seurain valtuuskunnan ohjeita vertaisarviointitunnuksen käytön edellytyksistä.

Kolmas uudistusehdotuksemme liittyy Vuoden vuorovaikutusteko -kunniamainintaan. Prologos ry aloitti Vuoden vuorovaikutusteko -kunniamaininnan jakamisen vuonna 2016 ja aiheesta on vuosittain uutisoitu yhdistyksen toimesta eri kanavissa sekä mediassa. Päätimme toimituskunnassa, että aloitamme uuden perinteen, jossa Vuoden vuorovaikutusteosta julkaistaan kirjoitus myös Prologissa. Tässä lehdessä on kaksi kirjoitusta, jotka liittyvät kyseiseen kunniamainintaan. Toinen niistä on näkökulma-artikkeli ja toinen on puheenvuoro. Jatkossa tavoitteemme on pyytää jokaista kunniamaininnan saajaa kirjoittamaan Vuoden vuorovaikutusteosta Prologiin. Näillä uudistuksilla toivomme Prologin herättävän mielenkiintoa entistä laajemman lukijakunnan keskuudessa myös tulevaisuudessa.

Tämä on järjestyksessään kolmastoista puheviestinnän vuosikirja ja se sisältää edellisten vuosikirjojen tavoin monipuolisia vuorovaikutukseen liittyviä tekstejä. Toimituskunnalle tarjottiin yhteensä kymmenen artikkeliehdotusta ja yksi ehdotus kirja-arviosta. Näistä hyväksyimme jatkotyöstettäväksi yhdeksän. Toimituskunnalle palautui määräpäivään mennessä seitsemän käsikirjoitusta. Näistä viisi päätettiin lähettää vertaisarviointiin ja yhdestä pyydettiin suoraan näkökulma-artikkeli. Kolme erillistä vertaisarvioijaa arvioi kunkin käsikirjoituksen. Vertaisarvioijat antoivat myönteisen signaalin kahdelle käsikirjoitukselle, joskin molempia käsikirjoituksia tuli muokata palautteen perusteella. Toimituskunta oli vertaisarvioijien kans- 
sa samaa mieltä ja edellytti, että lausunnoissa annetut parannusehdotukset huomioidaan käsikirjoituksen työstämisessä. Lopputuloksena on kaksi vertaisarvioitua artikkelia. Lisäksi julkaistaan yksi näkökulma-artikkeli, yksi puheenvuoro sekä kirja-arvio.

Ensimmäisessä vertaisarvioidussa artikkelissa Sisko Pikkumäki ja Maija Peltola tutkivat varhaiskasvatuksen opettajien käsityksiä ja havaintoja lapsiryhmissä ilmenneestä poissulkemisesta, joka on yksi yleisimmistä kiusaamisen muodoista pienten lasten keskuudessa. Pienten lasten kiusaamiseen kohdistuvaa viestinnän tutkimusta on tehty vähän. Pikkumäki ja Peltola osoittavat, että poissulkeminen on lastenvälisiin vuorovaikutussuhteisiin kytkeytyvä ilmiö, joka rakentuu interpersonaalisen ja ryhmäviestinnän tasoilla. Poissulkemiselle ei havaittu olevan mitään erityisiä perusteita, vaan syiden katsottiin vaihdelleen sen mukaan, millainen lapsiryhmä oli koolla ja millaisista vuorovaikutussuhteista ryhmä rakentui. Myös varhaiskasvatuksen opettajien käyttämät vaikuttamiskeinot kytkeytyivät vuorovaikutussuhteisiin liittyviin tekijöihin. Tärkeimmäksi vaikuttamiskeinoksi nähtiin varhaiskasvatustiimin jäsenten keskinäinen sekä lasten vanhempien kanssa tehtävä yhteistyö, joka parhaimmillaan mahdollisti yhteisistä käytännöistä sopimisen sekä koko kasvatusyhteisön viestinnän vaikutusten arvioimisen ja tiedostamisen.

Toisessa vertaisarvioidussa artikkelissa Tarja Tanttu keskittyy maahanmuuttajan ja työvoimaneuvojan väliseen vuorovaikutukseen ammatillisessa kontekstissa. Hän tutkii työvoimaneuvojan käsityksiä luottamuksen rakentamisesta ja merkityksestä työvoimaneuvojan ja maahanmuuttaja-asiakkaiden asiointikeskusteluissa. Tutkimuksessa työvoimaneuvojan käsityksiä jäsennetään identifikaatioon ja informaatioon pohjautuvan luottamuksen kategori- oiden avulla. Tulokset osoittavat muun muassa, että työvoimaneuvoja pyrkii virittämään asiakkaan luottamusta itseensä ja edustamaansa instituutioon esimerkiksi yhteistä viestinnällistä tilaa rakentamalla sekä itsestä kertomisen, huumorin ja myös muusta kuin hoidettavasta asiasta puhumisen avulla.

Vuonna 2016 Vuoden vuorovaikutusteko -kunniamaininnan sai Suomen Sovittelufoorumin puheenjohtaja Timo Pehrman sovittelutoiminnan istuttamisesta Suomeen. Sovittelu on vapaaehtoisuuteen perustuva vuorovaikutteinen menetelmä konfliktien ratkaisemiseen. Pia Lappalaisen näkökulma-artikkelissa kuvataan sovittelumenetelmä sekä osallistujien näkemyksiä menetelmän toimivuudesta. Kuvauksen perusteella on mahdollista ymmärtää menetelmää syvemmin ja ottaa se käyttöön omassa toimintaympäristössä.

Vuonna 2017 Prologos ry jakoi Vuoden vuorovaikutusteko -kunniamaininnan Juuan kunnanjohtaja Markus Hirvoselle ansiokkaasta ja innovatiivisesta tavasta osallistaa kuntansa nuoria. Hirvonen osallistui juukalaisten poikien mopomiittiin, jossa hän teinien kanssa mopoillessaan sai luotua arvokkaita vuorovaikutussuhteita nuoriin. Koskettavassa puheenvuorossaan hän kertoo kokemuksestaan sekä siihen johtaneista syistä. Hän myös kuvaa, kuinka tärkeää on ymmärtää, että jokaisella ihmisellä on sanottavaa. Aikuisten on tärkeää löytää yhteys ja luottamus nuoriin, sillä heissä on tulevaisuus.

Prologiin sisältyy kirja-arvio Pekka Isotaluksen teoksesta Mediapoliitikko. Sen on kirjoittanut Markus Mykkänen. Lisäksi mukana on professori Anu Sivusen virkaanastujaisesitelmä sekä lyhennetty versio professori Jennifer Gibbsin keynote-esitelmästä, joka pidettiin ECREA:n interpersonaalisen viestinnän alajaoston (Interpersonal Communication and Social Interac- 
tion) järjestämässä konferenssissa Helsingissä lokakuussa 2017. Konferenssin teema oli (Mediated) Social Interaction in Groups, Networks and Organizations.

Lopuksi haluan kiittää toimituskunnan jäseniä suuresta työstä, jonka olette tämän vuoden vuosikirjan eteen tehneet. Kiitos tehokkaasta ja miellyttävästä virtuaalisesta yhteistyöstä Lotta Kokkonen, Emma Kostiainen ja Ira Virtanen. Lämpimät kiitokset myös tämän vuoden vuosikirjaan tarjottujen käsikirjoitusten vertaisarvioijille.

Kuopiossa 22. marraskuuta 2017

Jonna Koponen

\section{Lähteet}

Korkeakoulutuksen ja tutkimuksen visio 2030. [online]. [viitattu 22.11.2017]. Opetus- ja kulttuuriministeriö. Saatavana www-muodossa: <URL: $\quad$ http://minedu.fi/korkeakoulutuksen-jatutkimuksen-visio-2030>

Siitonen, M. (2015). Puheen ja vuorovaikutuksen puolesta. Teoksessa M. Siitonen, M. Lahti, J. Koponen \& R. Vanhatalo (toim.) Prologi: puheviestinnän vuosikirja 2015. Jyväskylä: Prologos, 5-7.

Vertaisarviointitunnuksen käytön edellytykset. [online]. [viitattu 22.11.2017]. Tieteellisten seurain valtuuskunta. Saatavana www-muodossa: <URL: https://tsv.fi/fi/palvelut/tunnus/kayton-edellytykset> 